\title{
Effect of culture media and tissue extracts in the mantle explant culture of abalone, Haliotis varia Linnaeus
}

\author{
C.P. Suja ${ }^{a, *}$, N. Sukumaran ${ }^{b}$, S. Dharmaraj ${ }^{\text {a }}$ \\ ${ }^{\text {a }}$ Tuticorin Research Centre of Central Marine Fisheries Research Institute, Tuticorin, Tamil Nadu-628001, India \\ ${ }^{\mathrm{b}}$ Manonmanium Sundaranar University, Alwarkurichi-627412, Tirunelveli, Tamil Nadu, India
}

Received 16 July 2006; received in revised form 30 April 2007; accepted 30 April 2007

\begin{abstract}
The study is aimed at developing appropriate media for the mantle explant culture of abalone Haliotis varia. The effect of different media viz., L-15, Ham's F12, M199 was studied in combination with 10\% Fetal Calf Serum (FCS) and 10\% tissue extracts of gonad, mantle and whole body of abalone, H. varia to understand cell behaviour, cell yield and cell adherence in mantle explant culture of H. varia. Cultures with L-15 media gave better cell yield and M199 promoted better cell adherence. Addition of mantle extract to all media enhanced the cell yield to a maximum followed by whole body extract. Addition of whole body extract facilitated in cell adherence followed by the addition of mantle extract.
\end{abstract}

(C) 2007 Elsevier B.V. All rights reserved.

Keywords: Cell yield; Tissue extract; Basal media; Abalone

\section{Introduction}

Earlier reports indicated that cultures from adult tissues such as heart and mantle of marine molluscs were difficult to subcultivate successfully. Several attempts were made on the establishment of a molluscan permanent cell line from oysters including Crassostrea virginica, Ostrea edulis, Pinctada fucata, P. margaritifera, and from the clams, Mercenaria mercenaria, Mya arenaria and Spisula solisum (Chen and Wen, 1999; Ellis and Bishop, 1989; Machii et al., 1985b; Wen et al., 1993a).

Many of the earlier workers used different media for the explant culture of tissues of marine molluscs. Tripp

\footnotetext{
* Corresponding author. Tel.: +91 0461 2321515; fax: +91 0461 2322274

E-mail addresses: cpsuja@sancharnet.in, ttn_trccmfri@sancharnet.in (C.P. Suja).
}

(1963) reported the oyster heart explant culture in a medium consisting of seawater and animal sera. Perkins and Menzel (1964) found that oyster cells could be maintained up to 42 days in a medium containing various oyster extracts. Li et al. (1966) used M 199 with different additions for the culture of cardiac tissue cells from the oyster, C. virginica. Cecil et al. (1976) studied the effects of extracts from echinoderms on cell cultures of molluscs and echinoderms. Brewster and Nicholson (1979) used a medium prepared in a marine saline and supplemented with fetal bovine serum and other supplements for in-vitro maintenance of amoebocytes from the American oyster, C. virginica.

Machii et al. (1985b) used Medium Hd-1 for the establishment of a cell line from abalone, Haliotis discus. Machii et al. (1985a) and Machii and Wada (1989) used a medium Pf-35 for the explant culture of the tissue of P. fucata, P. margaritifera and other marine invertebrates. 
Chen et al. (1989) and Ellis and Bishop (1989) used the medium Ham's F-10 for the cell culture of veliger larvae of oyster, C. virginica and clams, M. mercenaria. Wen et al. (1993a,b) used double strengthened L-15 medium with supplements for the culture of oyster, C. gigas and the hard clam, Meretrix lusoria. Coulon et al. (1994) reported a medium containing hormones, growth factor antioxidants and lipids, which enhanced the cell viability of primary cell cultures of $C$. gigas oyster. Mathieu and Boucaud (1995) used M 199 and L-15 for cell suspension of bivalve molluscs. Cornet (1995) incorporated chick embryo extract in the place of egg yolk for culture medium enrichment. Naganuma et al. (1996) used modified L-15 medium for the culture of cells from the trochophore larvae of the abalone, $H$. discus. Lebel et al. (1996) reported response of primary cultures of abalone haemocytes to vertebrate growth factors. CroqMarrec Le et al. (1999) reported primary cultures of heart cells from the scallop Pectan maximus. Chen and Wen (1999) used double strengthened L-15 medium with supplements for the culture of oyster, C. gigas and hard clam, M. lusoria. Cornet (2000) reported replacement of fowl embryo extract with fowl serum for medium enrichment. Buchanan et al. (2001) studied the influence of substrates and culture media formulations on the attachment and spreading of eastern oyster cells in primary cultures. Barik et al. (2004) reported the in-vitro explant culture of mantle epithelium of fresh water pearl mussel in Dulbecco's Modified Eagle medium enriched with fetal bovine serum. Cornet (2006) studied the growth promoting activity of serum in the primary mantle tissue culture of bivalve mollusc Mytilus galloprovincialis.

Fankboner (1991a,b) developed a technique of producing round pearl by inserting a shell bead in a hole made on abalone shell. Suja and Dharmaraj (2005) in their first report, obtained nacre layer formation in the in-vitro explant mantle tissue of abalone $H$. varia using the medium M 199 with supplements, a modified medium of Machii and Wada (1989). They further succeeded in developing a basic technology on the production of in-vitro pearl through organ culture and the results were incorporated in patenting the technology (Dharmaraj and Suja, 2004, 2006). In order to develop still an effective and best culture medium and to boost the cell yield and cell adherence, the present trial on using tissue extracts has been taken up. This study reports the effect of different culture media viz., L-15, Ham's F12 and M199 with $10 \%$ fetal calf serum as basal media with tissue extracts of gonad, mantle and whole body of the abalone, H. varia on cell behaviour, cell yield and cell adherence in the mantle explant culture of the abalone, H. varia.

\section{Materials and methods}

\subsection{Collection and selection of abalones}

The abalones, H. varia in the size range of $35 \times 20-$ $55 \times 38 \mathrm{~mm}$ in length $\times$ breadth, were collected from the natural habitat of break waters of Tuticorin Bay on the day of experiment. The biological and physiological condition of abalones used in the study was found similar as they were collected from the same habitat. However utmost care was taken to avoid any disparity among the specimens during selection. The procedures for excising, washing and inoculation of abalone tissues were followed as described previously (Suja and Dharmaraj, 2005).

\subsection{Preparation of tissue extracts}

Two to three sexually matured abalones of both sexes were sacrificed to obtain whole body tissue. It was chopped and mixed thoroughly. A sample of $10 \mathrm{~g}$ tissue was chosen for extract preparation. Similarly eight to ten sexually matured abalones of both sexes were used for the extraction of mantle and gonad tissue.

$10 \mathrm{~g}$ of tissue of each organ was homogenized in a tissue homogenizer in $100 \mathrm{ml}$ of $50 \%$ seawater in double distilled water. The homogenized tissues were centrifuged at $3000 \mathrm{rpm}$ for $10 \mathrm{~min}$ and the supernatant was collected. The centrifugation was repeated 3 or 4 times for easy filtration through the $0.22 \mu \mathrm{m}$ filter paper. The supernatant was inactivated at $56{ }^{\circ} \mathrm{C}$ for $30 \mathrm{~min}$ in a water bath. It was filtered through $0.22 \mu \mathrm{m}$ filter paper with vacuum pump (Superfit, India). The filtered extracts were stored separately in sterile bottles. From these stock solutions of extracts, media with different compositions were prepared as in Table 1. $\mathrm{pH}$ of each media was adjusted to 7.8 .

Table 1

Composition of media

$2 \times \mathrm{L}-15+10 \%$ FCS (Basal Medium I or BM I)

BM $1+10 \%$ Gonad Extract (GE)

BM $1+10 \%$ Mantle Extract (ME)

BM $1+10 \%$ Whole body Extract (WBE)

$2 \times$ F $12+10 \%$ FCS (Basal Medium II or BM II)

$\mathrm{BM} \mathrm{II}+10 \%$ Gonad Extract (GE)

BM II + 10\% Mantle Extract (ME)

BM II $+10 \%$ Whole body Extract (WBE)

$2 \times$ M199 $+10 \%$ FCS (Basal Medium III or BM III)

BM III $+10 \%$ Gonad Extract (GE)

BM III $+10 \%$ Mantle Extract (ME)

$\mathrm{BM}$ III $+10 \%$ Whole body Extract (WBE) 
L-15, Ham's F12 and M199 double strengthened media $(2 \times)$ (HiMedia) with $10 \%$ FCS (Sigma) were used as basal media I, II and III respectively. The basal media were supplemented with $10 \%$ of the extracts of gonad (GE), mantle (ME) and whole soft body (WBE) as given in Table 1.

\subsection{Assessment of cell yield and adherence}

Cell yield was assessed by taking out the cells simultaneously from all the three replicates of culture plates with three explants each on day 8 . The average cell yield from each media composition was assessed using haemocytometer and the cell yield pattern was monitored regularly in all culture plates. The rate of cell adherence was compared by observing fixed cells on the culture plates as + refers to $15-30 \%,++30-45 \%$, ++ $45-60 \%,+++60-75 \%$ of cell adherence.

\subsection{Statistical analysis}

Mean differences were compared using one way Analysis of variance (ANOVA) and a post-hoc LSD (Least Square Difference) test was carried out using SPSS software.

\section{Results}

\subsection{Cell type and cell size}

Twenty-four hours after initiating the mantle explant cultures, numerous cells were observed surrounding the explant. The cells were of different morphological types such as granulocytes, fibroblast-like cells and hyalinocytes. Sizes of the cells were similar as reported in our earlier paper and there was no variation among the different media compositions. They migrated away from the explant. Some adhered cells near the explant developed pseudopodia from day one onwards and formed a network like arrangement covering a large area in subsequent days.
The adherence of cells and development of pseudopodia differed in different media compositions.

No contamination of bacteria, fungi and thraustochytrid was encountered in the study as the cultures were maintained only for a short period.

\subsection{Adherence and yield of cells}

The maximum cell adherence was observed in culture plates using BM III (M 199) and its tissue extracts (Table 2). Cell adherence and a short pseudopodia network were also observed in the plates using BM I (L-15) and its tissue extracts. The pseudopodial network was not observed in cultures using BM II (F12) and with tissue extracts except a lone occurrence of pseudopodial network in a plate with BM II with ME. Yield of cells was more in BM I and less with BM II without any tissue extracts. However cultures with BM II liberated more cells when incorporated with tissue extracts (Table 2). Statistically there was no significant difference between treatments with different basal media. Significant difference in cell yield was observed between treatments incorporated with tissue extracts. Maximum significant difference was observed between treatments with mantle extract and basal medium and next between treatments with whole body and basal medium in all three media (L-15, F12 and M199) compositions.

\subsubsection{Cultures using L-15 as basal medium (BM I) with extracts}

Soon after incubation, cells in cultures using L-15 (BM I) began to migrate from the explants and found attached with short pseudopodia developing a small network. No pseudopodial network was observed in cultures supplemented with GE whereas in ME a pseudopodial network of $100 \mu \mathrm{m}$ width was recorded. A comparatively larger pseudopodial network of $150 \mu \mathrm{m}$ could be found in WBE. The cell yield was at maximum in cultures using medium incorporated with $\mathrm{ME}$ and minimum in culture using BM 1 without any extract

Table 2

Cell yield $($ mean $\pm \mathrm{SD})$ and cell adherence in media L15, F12 and M199 with tissue extracts

\begin{tabular}{|c|c|c|c|c|c|c|}
\hline \multirow[t]{2}{*}{ Medium with extracts } & \multicolumn{2}{|l|}{ L 15 (BMI) } & \multicolumn{2}{|l|}{ F12 (BMII) } & \multicolumn{2}{|l|}{ M199 (BMIII) } \\
\hline & Cell yield $\times 10^{4}$ cells $/ \mathrm{ml}$ & $\begin{array}{l}\text { Cell } \\
\text { adherence }\end{array}$ & Cell yield $\times 10^{4}$ cells $/ \mathrm{ml}$ & $\begin{array}{l}\text { Cell } \\
\text { adherence }\end{array}$ & Cell yield $\times 10^{4}$ cells $/ \mathrm{ml}$ & $\begin{array}{l}\text { Cell } \\
\text { adherence }\end{array}$ \\
\hline $\mathrm{BM}$ & $5.06 \pm 0.39$ & + & $4.06 \pm 0.22$ & - & $4.75 \pm 1.13$ & ++ \\
\hline $\mathrm{BM}+\mathrm{GE}$ & $5.13 \pm 0.18$ & - & $5.75 \pm 0.84$ & - & $5.32 \pm 1.26$ & ++ \\
\hline $\mathrm{BM}+\mathrm{ME}$ & $7.19 \pm 1.07$ & ++ & $8.00 \pm 2.60$ & + & $8.72 \pm 1.77$ & ++ \\
\hline $\mathrm{BM}+\mathrm{WBE}$ & $6.79 \pm 0.82$ & ++ & $6.48 \pm 1.04$ & - & $6.94 \pm 1.09$ & +++ \\
\hline
\end{tabular}

+ refers to $15-30 \%,++30-45 \%,++45-60 \%,+++60-75 \%$ of cell adherence.

$\mathrm{BM}$ - basal medium; GE — gonad extract; ME — mantle extract; WBE — whole body extract. 
(Table 2). Significant difference in cell yield was observed between all the treatments, $P=0.002$ (Table 3). Significant differences were not observed between treatments with BM I with GE and between media with ME and WBE. Maximum significance was observed between treatments using BM I and BM I with ME and BM I with GE and BM I with ME. Significant differences were also observed between treatments of BM I and BM I incorporated with WBE and between media incorporated with GE and WBE.

\subsubsection{Cultures using F12 as basal medium (BM II) with extracts}

Cells obtained in cultures using basal medium F-12 developed very small pseudopodia whereas in cultures incorporated with GE, and WBE no pseudopodial network could be found. However in cultures with ME there was a network of pseudopodia. The number of cells released was maximum in BM II with $\mathrm{ME}$ and minimum with BM II without any extracts. Significant difference was observed between all treatments $(P=0.018)$ (Table 3). There was no significant difference between treatments BM II and BM II with GE; BM II with GE and BM II with ME; BM II with GE and BM II with WBE and BM II with ME and BM II with WBE. Treatments between BM II and BM II with ME and with BM II and BM II with WBE were highly significant as shown in Table 3.

\subsubsection{Cultures using M199 as basal medium (BM III) with extracts}

Most of the cells liberated from the explants were developed pseudopodia. The pseudopodial network

Table 3

Results of analysis of variance and least square difference test (LSD) in cell yield in the explant culture of mantle tissue of $H$. varia with different media

\begin{tabular}{|c|c|c|c|c|c|c|}
\hline & \multicolumn{6}{|c|}{ Analysis of variance (ANOVA) } \\
\hline & Treatments & Sum of squares & $d f$ & Mean square & $F$ & $\mathrm{P}$ \\
\hline \multirow[t]{7}{*}{ With three basal media, L15, F12 and M199 } & Between groups & 2.103 & 2 & 1.051 & 2.161 & 0.171 \\
\hline & Within groups & 4.379 & 9 & 0.487 & & \\
\hline & Total & 6.481 & 11 & & & \\
\hline & \multicolumn{6}{|c|}{ Least square difference (LSD) } \\
\hline & & F12 & M199 & & & \\
\hline & L15 & 0.073 & 0.539 & & & \\
\hline & F12 & 0.197 & & & & \\
\hline \multirow[t]{9}{*}{ With basal medium L15 and with $10 \% \mathrm{GE}, \mathrm{ME}$ and WBE } & \multicolumn{6}{|c|}{ Analysis of variance (ANOVA) } \\
\hline & Between groups & 14.728 & 3 & 4.909 & 9.764 & $0.002 *$ \\
\hline & Within groups & 6.034 & 12 & 0.503 & & \\
\hline & Total & 20.762 & 15 & & & \\
\hline & \multicolumn{6}{|c|}{ Least square difference (LSD) } \\
\hline & & $\mathrm{BMI}+\mathrm{GE}$ & $\mathrm{BMI}+\mathrm{ME}$ & $\mathrm{BMI}+\mathrm{WBE}$ & & \\
\hline & L15 (BMI) & 0.903 & $0.001^{*}$ & $0.005^{*}$ & & \\
\hline & $\mathrm{BMI}+\mathrm{GE}$ & $0.001^{*}$ & $0.006^{*}$ & & & \\
\hline & $\mathrm{BMI}+\mathrm{ME}$ & & 0.440 & & & \\
\hline \multirow[t]{9}{*}{ With basal medium F12 and with $10 \% \mathrm{GE}, \mathrm{ME}$ and WBE } & \multicolumn{6}{|c|}{ Analysis of variance (ANOVA) } \\
\hline & Between groups & 32.104 & 3 & 10.701 & 4.962 & $0.018^{*}$ \\
\hline & Within groups & 25.880 & 12 & 2.157 & & \\
\hline & Total & 57.984 & 15 & & & \\
\hline & \multicolumn{6}{|c|}{ Least square difference (LSD) } \\
\hline & & $\mathrm{BMII}+\mathrm{GE}$ & $\mathrm{BMII}+\mathrm{ME}$ & $\mathrm{BMII}+\mathrm{WBE}$ & & \\
\hline & F12 (BMII) & 0.130 & $0.003^{*}$ & $0.038^{*}$ & & \\
\hline & $\mathrm{BMII}+\mathrm{GE}$ & $0.051^{*}$ & 0.496 & & & \\
\hline & $\mathrm{BMII}+\mathrm{ME}$ & & 0.169 & & & \\
\hline \multirow[t]{9}{*}{ With basal medium M199 and with $10 \% \mathrm{GE}, \mathrm{ME}$ and WBE } & \multicolumn{6}{|c|}{ Analysis of variance (ANOVA) } \\
\hline & Between groups & 38.268 & 3 & 12.756 & 7.122 & $0.005 *$ \\
\hline & Within groups & 21.493 & 12 & 1.791 & & \\
\hline & Total & 59.761 & 15 & & & \\
\hline & \multicolumn{6}{|c|}{ Least square difference (LSD) } \\
\hline & & $\mathrm{BMIII}+\mathrm{GE}$ & $\mathrm{BMIII}+\mathrm{ME}$ & $\mathrm{BMIII}+\mathrm{WBE}$ & & \\
\hline & M199 (BMIII) & $0.5 \mathrm{w} 56$ & $0.001^{*}$ & $0.039^{*}$ & & \\
\hline & $\mathrm{BMIII}+\mathrm{GE}$ & $0.004^{*}$ & 0.113 & & & \\
\hline & $\mathrm{BMIII}+\mathrm{ME}$ & & & 0.084 & & \\
\hline
\end{tabular}

*Significant at $P<0.05$. 
formed to the extent of $200 \mu \mathrm{m}$ width with BM III. The maximum cell adherence and a large cell sheet were observed in culture plates using BM III with WBE up to $300 \mu \mathrm{m}$ width and next in cultures using BM III with ME up to $250 \mu \mathrm{m}$ width and less in culture plates with GE. Pseudopodial network was not observed in cultures using BM III with GE. Maximum cell yield was found in plates supplemented with ME followed by WBE, GE respectively and minimum in BM III without any extracts. The maximum significance was observed in treatments between BM III and BM III with ME (Table 3). Significant difference in cell yield was also observed when considering all treatments and also between treatments with BM III incorporated with GE and BM III with ME and BM III and BM III with WBE. Significant difference was not observed between treatments BM III and BM III with GE; BM III with GE and BM III with WBE and BM III with ME and BM III with WBE.

\section{Discussion}

Earlier workers have tried different culture media for explant tissue culture of marine molluscs. In the present study three different culture media L-15, F12 and M199 along with $10 \%$ FCS were used individually as basal media and also in combination with different tissue extracts of gonad, mantle and whole body to develop appropriate media for good cell yield and cell adherence.

\subsection{Effect of basal media}

L-15 media was tested for its quality in promoting cell yield and cell adherence by various authors. Wen et al. (1993a,b) found that L-15 medium was a suitable basic medium for in-vitro cell cultures of oyster and hard clam tissue. The performance of individual basal medium has limited potential in cell yield. Cornet (2006) investigated the growth promoting activity of the serum used for medium supplementation in the primary mantle tissue culture from the bivalve mollusc $M$. galloprovincialis and reported that best results were obtained using $20 \%$ chicken serum and $30 \%$ fetal calf serum. In the present study, the performance of the basal medium L-15 was better than Ham's F 12 and M199 in cell yield and in cell adherence M199 was better than L-15 and F12.

\subsection{Effect of tissue extracts}

Chen and Wen (1999) suggested that addition of proline or taurine to the growth media L-15 was considered necessary to enhance the survival of oyster cells. They also tried the addition of fibroblast growth factor, epidermal growth factor, endothelial growth media or nutridoma into culture medium L-15 to assist cell growth and they did not obtain positive results in C. gigas. Wen et al. (1993a) reported 6 time-subculture of the explant culture of oyster heart using L-15 medium with oyster gonad extract and rabbit or bovine pituitary gland extract and they considered that these extracts could promote cell yield. The sustainability of L-15 medium with gonad extract was evidenced by subcultures. Coulon et al. (1994) used a medium containing hormones, growth factor antioxidants and lipids with an aim to study viability of cells of pacific oyster, $C$. gigas and to formulate a superior growth medium. Chen and Wen (1999) used the extract from oyster reproductive gland and found to prolong the survival of oyster cells in-vitro. The results are identical to the present study where the L-15 basal medium with $10 \% \mathrm{GE}, \mathrm{ME}$ and WBE gave slightly better cell yield. Maximum cell yield was recorded with ME than other extracts.

Similarly Ellis and Bishop (1989), while isolating cultured cells from marine bivalve molluscs, used the culture medium Ham's F10 supplemented with some amino acids and found a limited growth. In the present study, Ham's F-12 when combined with ME resulted in high cell yield, whereas the basal medium alone gave poor cell yield.

The basal medium M199 was prevalently used in cultures like other basal media. Li et al. (1966) reported that addition of bovine amniotic fluid, human serum and salt solution supplements to the M199 was essential for the initiation and maintenance of oyster cell. Tripp (1963) found out a better response by the oyster tissue in a $10 \%$ calf serum in seawater medium than in commercial vertebrate tissue culture media. Croq-Marrec Le et al. (1999) reported primary cultures of Pecten maximus in which the medium based sterile sea water has promoted cell attachment to the plastic medium. Incorporation of leucine, thymidine and acetate confirmed functional activity of the cells. Buchanan et al. (2001) reported that cell attachment, cell survival and RNA production were all significantly affected by the media and the substrate in the ventricle cells of $C$. virginica and indicated that response of cells varied with the media components and substrates. A similar result was also obtained in the present study in $H$. varia where the cell yield and cell adherence varied with different media with different extracts. Suja and Dharmaraj (2005) reported nacre layer formation in explant mantle tissue culture of $H$. varia with $10 \%$ fetal calf serum where adhered cells by their interaction deposited crystals on the substratum itself in the culture flask. 
There was no shell bead like material provided and hence no pearl sac formation occurred. In their further study on organ culture of both pearl oyster P. fucata and abalone $H$. varia, shell bead was provided which got coated with micron layers of nacre after pearl sac formation (Dharmaraj and Suja, 2004, 2006). These results were possible only when in-vitro cell adherence occurred. The success achieved in organ culture is a challenging aspect in pearl culture industry where the possibility of production of free in-vitro pearls on commercial basis is unlimited, whereas it is rather difficult in producing free pearls on large scale through the technique developed by Fankboner (1991a,b).

\section{Conclusion}

Among the basal media, L-15 gave better cell yield and M199 promoted better cell adherence. All the three basal media supplemented with ME enhanced the cell yield followed by WBE. The cell adherence was comparatively high with the supplement of WBE followed by ME. It is known from the present study that each extract performed specific function of promoting better cell yield and cell adherence.

\section{Acknowledgements}

We express our gratitude to the Director, Central Marine Fisheries Research Institute, Cochin and to the Head, Molluscan Fisheries Division, CMFRI, Cochin for their encouragement in this study. We are also indebted to the Department of Biotechnology, New Delhi for their finance in establishment of the first ever marine invertebrate tissue culture laboratory at Tuticorin and to the National Agricultural Technology Project (NATP) for additional fund during the course of study.

\section{References}

Barik, S.K., Jena, J.K., Janaki Ram, K., 2004. In-vitro explant culture of mantle epithelium of fresh water pearl mussel. Indian J. Exp. Biol. 42, 1235-1238.

Brewster, F., Nicholson, B.L., 1979. In-vitro maintenance of amoebocytes from the Americal oyster (Crassostrea virginica). J. Fish. Res. Board Can. 36, 461.

Buchanan, J.T., Li, Y., La-Peyre, J.F., 2001. The influence of substrates and culture media formulations on the attachment and spreading of eastern oyster cells in primary cultures. Aquaculture. 2001 Book of abstracts. World Aquacult. Society, p. 95.

Cecil, J.T., Ruggieri, G.D., Nigrelli, R.F., 1976. Effects of extracts from echinoderms on cell cultures from molluscs and echinoderms. In: Kurstak, E., Maramorosch, K. (Eds.), Invertebrate Tissue culture: Applications in Medicine, Biology Agriculture, 29. Academic press, New York, pp. 301-307.
Chen, S.N., Wen, C.M., 1999. Establishment of cell lines derived from oyster, Crassostrea gigas Thunberg and hard clam, Meretrix lusoria Roding. Methods Cell Sci. 21, 183-192.

Chen, C.P., Hsu, H.W., Lei, S.F., Chang, C.H., 1989. Preliminary study on the cryopreservation of Pacific oyster oocytes. J. Fish. Soc. Taiwan 16, 197-201.

Cornet, M., 1995. A study of some factors affecting the efficiency of in-vitro mussel tissue culture for chromosome preparation. Cytobios 84 (336), 7-12.

Cornet, M., 2000. Obtaining cell proliferation for chromosome preparation in gill tissue culture of the oyster, Crassostrea gigas. Cytotechnology 32 (1), 1-7.

Cornet, M., 2006. Primary mantle tissue culture from the bivalve mollusc Mytilus galloprovincialis: investigations on the growth promoting activity of the serum used for medium supplementation. J. Biotechnol. 123 (1), 78-84.

Coulon, I.D., Doumence, D., Bordenave, S.A., Fichant, L.Y., 1994. Identification of media supplements that improve the viability of primary cell cultures of Crassostrea gigas oysters. Cytotechnology $16,109-120$.

Croq-Marrec Le, F., Glaise, D., Guillouzo, G.C., Chesne, C., Guillouzo, A., Boulo, V., Dorange, G., 1999. Primary cultures of heart cells from the Scallop Pecten maximus (Mollusca-Bivalvia). In Vitro Cell. Dev. Biol., Anim. 35, 289-295.

Dharmaraj, S., Suja, C.P., 2004. Pearl production techniques through tissue culture in the Indian pearl oyster (Pinctada fucata) and in the abalone (Haliotis varia) and other pearl producing molluscs. Indian patent No.,1987/DEL/04 (IPR-Indian Council of Agricultural Research).

Dharmaraj, S., Suja, C.P., 2006. Pearl production techniques through tissue culture in the Indian pearl oyster (Pinctada fucata) and in the abalone (Haliotis varia) and other pearl producing molluscs. International Patent No., PCT/IB 2006/003299.

Ellis, L.L., Bishop, S.H., 1989. Isolation of cell lines with limited growth potential from marine bivalves. In: Mitsuhashi, J. (Ed.), Invertebrate cell system Applications, 2. CRC press, Boca Raton, Florida, pp. 243-251.

Fankboner, P.V., 1991a. Pearl culture in abalone. Info. Fish Int. 4, $52-55$.

Fankboner, P.V., 1991b. Pearl Culture in the Abalone Haliotis. Final report to B.C. Science Council. 33 pp.

Lebel, J.M., Giard, W., Favrel, P., Boucaud-Camou, E., 1996. Effects of different vertebrate growth factors on primary cultures of hemocytes from the gastropod mollusc, Haliotis tuberculata. Biol. Cell 86 (1), 67-72.

Li, M.F., Stewart, J.E., Drinnan, R.E., 1966. In vitro cultivation of cells of the oyster, Crassostrea virginica. J. Fish. Res. Board Can. 23, 585 .

Machii, A., Wada, K.T., 1989. Some marine invertebrates tissue culture. In: Mitsuhashi, J. (Ed.), Invertebrate Cell System application, 2. CRC Press, Boca Raton, Florida, pp. 226-233.

Machii, A., Wada, K.T., Townsley, S.J., Sasaki, K., Awaji, M., 1985a. Tissue culture of some marine invertebrates. Application of invertebrate cells in vitro presented at Satel., Symp. 3rd Int. Cell. Cult. Cong., Sendai, Japan, September 14, 1985.

Machii, A., Wada, K.T., Sasaki, K., Awaji, M., Townsley, S.J., 1985 b. Establishment of a cell line from the abalone Haliotis discus (Mollusca). Presented at Satel. Symp.3rd Int. Cell Cult. Cong., Sendai, Japan, Sept.14,1985.

Mathieu, M., Boucaud, E., 1995. Growth factors. Biology of protozoa, Invertebrates and fishes: In-vitro experimental models and applications. In: Dorange, G., Guillouza, C., Samain, J.F. (Eds.), 
European workshop, Brest, 29-30. April. 1994, 18. IFREMER, Plouzane, France, p. 31.

Naganuma, T., Akutsu, T., Ishida, T., Kato, C., Horikoshi, K., 1996. In site RT-PCR from the betatubulin in RNA in abalone cells in primary cultures. J. Mar. Biotech. 4 (2), 75-81.

Perkins, F.O., Menzel, R.W., 1964. Maintenance of oyster cells in-vitro. Nature 204, 1106-1107.

Suja, C.P., Dharmaraj, S., 2005. In-vitro culture of mantle tissue of the abalone, Haliotis varia (Linnaeus). Tissue Cell 37 (1), 1-10.
Tripp, M.R., 1963. Cellular response of molluscs. Ann. N.Y. Acad. Sci. 113, 467-474.

Wen, C.M., Kou, G.H., Chen, S.N., 1993a. Establishment of cell lines from the pacific oyster. In vitro cell. Dev. Biol. 294, 901-903.

Wen, C.M., Kou, G.H., Chen, S.N., 1993b. Cultivation of cells from the heart of the heart clam, Meretrix lusoria (Roding). J. Tissue Cult. Methods 15, 123-130. 